(C) В.М. Шимон, В.В. Стойка, С.С. Філіп, А.А. Шерегій, I.І. Пушкаш, 2020

УДК: 616.711.6-018.3-002.28-08:615.849.19]:001.82

\title{
Аналіз результатів лікування стабільних форм остеохондрозу
}

\author{
В.М. Шимон, В.В. Стойка, С.С. Філіп, А.А. Шерегій, I.І. Пушкаш
} ДВНЗ «Ужсгородський національний університет», медичний факультет, кафедра загальної
хірургій, Ужгород

\section{Реферат}

Вступ. Остеохондроз поперекового відділу хребта є однією з найчастіших причин болю в нижній частині спини. Консервативне лікування дозволяє отримати добрий результат у переважної більшості пацієнтів. Проте в великої кількості хворих така тактика виявляється неефективною.

Відкриття лазерних технологій та впровадження їх в медичну практику призвели до популяризації малоінвазивних методів лікування. Лазерна вапоризація міжхребцевих дисків дозволяє усунути больовий та корінцевий синдроми за допомогою випарювання (вапоризації) невеликого об’єму пульпозного ядра.

Мета дослідження. Провести ретроспективний аналіз лікування стабільних форм остеохондрозу поперекового відділу хребта.

Матеріали та методи. В клініці кафедри загальної хірургії ДВНЗ «Ужгородський національний університет» за 20092019 роки було проліковано 1126 пацієнтів зі стабільними формами остеохондрозу поперекового відділу хребта. Всі хворі були працездатного віку. Серед них було 630 жінок (56,0\%), 496 чоловіків (44,0\%). Хворих поділено на три групи: 1 хворі, яким проводилось консервативне лікування (584); 2 - хворі, яким проводилось відкрите оперативне втручання (303); 3 - хворі, яким проводилась черезшкірна лазерна вапоризація міжхребцевого диску (239).

Результати досліджень та їх обговорення. Відмінний та добрий результат серед всіх хворих першої групи, що спостерігались нами протягом першого року, склав 68\%. 42 хворих з цієї групи були прооперовані через відсутність ефекту від консервативного лікування в різні терміни від початку терапії.

Серед хворих другої групи кількість відмінних та добрих результатів склала протягом першого року $74 \%$. Більшість хворих повернулись на свою попередню роботу. 37 хворих були вимушені змінити роботу. Повторно прооперовано 21 хворого: 18 хворих на інших рівнях та 3 хворих на рівні попереднього оперативного втручання.

Серед хворих III групи протягом 1 року успішні результати простежувалися в 77,1\%. У 15 хворих покращення не виявлено. Один був прооперований відкритим методом.

Висновки. Черезшкірна лазерна вапоризація міжхребцевих дисків $\epsilon$ альтернативою відкритому хірургічному втручанню, проте необхідно дотримуватись чітких показів та протипоказів до виконання даного втручання. Актуальним $є$ вивчення віддалених результатів (більше 6 років) після проведення черезшкірної лазерної вапоризації міжхребцевих дисків.

Ключові слова: остеохондроз, поперековий відділ хребта, лазерна вапоризація, нуклеотомія.

Analysis of the results of treatment of stable forms of osteochondrosis

V.M. Shymon, V.V. Stoika, S.S. Filip, A.A. Sherehii, I.I. Pushkash

Uzhhorod National University, Medical Faculty, Department of General Surgery, Uzhhorod

\section{Abstract}

Introduction. Osteochondrosis of the lumbar spine is one of the most common causes of lower back pain. Conservative treatment can get a good result in the vast majority of patients. However, in a large number of patients this tactic is ineffective.

The discovery of laser technologies and their introduction into medical practice have led to the popularization of minimally invasive treatments. Laser vaporization of intervertebral discs can eliminate pain and radicular syndromes by evaporation (vaporization) of a small volume of the pulpal nucleus.

The aim of the study. Conduct a retrospective analysis of the treatment of stable forms of lumbar spine osteochondrosis.

Materials and methods. In 2009-2019, 1126 patients with stable forms of osteochondrosis of the lumbar spine were treated in the clinic of the Department of General Surgery of Uzhhorod National University. All patients were of working age. Among them were 630 women $(56.0 \%), 496$ men $(44.0 \%)$. Patients were divided into three groups: 1 - patients who underwent conservative treatment (584); 2 - patients who underwent open surgery (303); 3 - patients who underwent percutaneous laser vaporization of the intervertebral disc (239).

Results and discussion. Excellent and good result among all patients of the first group, which we observed during the first year was $68 \% .42$ patients from this group were operated due to the lack of effect of conservative treatment at different times from the start of therapy.

Among patients of the second group the number of excellent and good results during the first year was 74\%. Most patients returned to their previous jobs. 37 patients were forced to change jobs. 21 patients were re-operated: 18 patients at other levels and 3 patients at the level of previous surgery.

Among patients of group III within 1 year successful results were noted in $77.1 \%$. No improvement was observed in 15 patients. One was operated on by the open method.

Conclusions. Percutaneous laser vaporization of intervertebral discs is an alternative to open surgery, but it is necessary to follow clear indications and contraindications to perform this procedure. It is important to study long-term results (more than 6 years) after percutaneous laser vaporization of intervertebral discs.

Key words: osteochondrosis, lumbar spine, laser vaporization, nucleotomy. 
Вступ. Остеохондроз поперекового відділу хребта $\epsilon$ однією 3 найчастіших причин болю в нижній частині спини. Консервативне лікування дозволяє отримати добрий результат переважної більшості пацієнтів. Проте в великої кількості хворих така тактика виявляється неефективною. Переваги та недоліки відкритого хірургічного втручання стали предметом дискусій декількох поколінь науковців та практичних лікарів [1]. Cеред недоліків найбільше значення має велика травматичність для хворого, тривала втрата працездатності, тривалий післяопераційний больовий синдром, розвиток післяопераційної нестабільності у оперованому сегменті, розвиток післяопераційного фіброзу i рубцево-спайкових процесів, значний відсоток септичних ускладнень [2].

Технічних прогрес відкрив нові шляхи вирішення проблеми. Відкриття лазерних технологій та впровадження їх в медичну практику призвели до популяризації малоінвазивних методів лікування. Лазерна вапоризація міжхребцевих дисків дозволяє усунути больовий та корінцевий синдроми за допомогою випарювання (вапоризації) невеликого об'єму пульпозного ядра. Зазвичай терапевтичний ефект наступає у ранньому післяопераційному періоді та посилюється в більш віддалені терміни за рахунок фібротизації диску з втягуванням протрузії або кили [3].

Вперше лазерна вапоризація міжхребцевого диску була виконана у 1986 році в клініці університету м. Грац в Австрії лікарями Р. Asher та D. Choy [4]. Після уточнення показів та техніки виконання даної маніпуляції дискусія зосередилась над питанням вибору довжини хвилі лазерного випромінювання. Оскільки пульпозне ядро складається на 70,85\% з води, то необхідна довжина хвилі, яка найбільше поглинається у воді. Більше поглинання означає меншу енергію, необхідну для вапоризації, а менша енергія означає менше пошкодження навколишніх тканин. Оптимальним $\epsilon$ також забезпечення стимуляції регенераторних процесів тканини пульпозного ядра, що також буде сприяти позитивному післяопераційному результату [5].

Мета дослідження. Провести ретроспективний аналіз лікування стабільних форм остеохондрозу поперекового відділу хребта.

Матеріали та методи. У клініці кафедри загальної хірургії ДВНЗ «Ужгородський національний університет» за 2009-2019 роки було проліковано 1126 пацієнтів зі стабільними формами остеохондрозу поперекового відділу хребта. Всі хворі були працездатного віку. Серед них було 630 жінок (56,0\%), 496 чоловіків (44,0\%). Корінцева симптоматика була наявна в 738 хворих (чоловіки - 430, жінки - 308). У 642 хворих (жінок - 343, чоловіків - 299) був наявний виражений міотонічний та больовий синдром. За віком хворі були розподілені в такі групи: від 20 до 30 років - 181 пацієнт $(16,1 \%)$, від 30 до 40 років -
318 пацієнтів (28,2\%), від 40 до 50 років - 474 пацієнти $(42,1 \%), 50$ років і старше - 153 пацієнти $(13,6 \%)$. Давність захворювання була така: до 1 місяця - 98 хворих (8,7\%), 1-3 місяці - 124 хворих (11,0\%), 3-6 місяців - 153 хворих $(13,6 \%)$, 6-12 місяців - 322 хворих $(28,6 \%)$, більше 1 року - 429 (38,1\%). Консервативне лікування отримало 584 хворих. Консервативна терапія включала нестероїдні протизапальні препарати (НПЗП), дегідратацію, периферичні міорелаксанти, фізіопроцедури, венотоніки, витяжіння, епідуральні блокади. 542 хворих було прооперовано, 3 них 239 хворих $(44,1 \%)$ методом черезшкірної лазерної вапоризації міжхребцевого диску. Для уточнення розмірів та локалізації всім хворим виконували КТ або МРТ. Показом до черезшкірної лазерної вапоризації була неефективність консервативної терапії протягом 6 тижнів та наявність протрузії або несеквестрованої кили міжхребцевого диску до 6-8 мм 3 або без неврологічної симптоматики. Хворі були поділені на три групи: 1 - хворі, яким проводилося консервативне лікування (584); 2 - хворі, яким проводилося відкрите оперативне втручання (303); 3 - хворі, яким проводилася черезшкірна лазерна вапоризація міжхребцевого диску (239).

Больовий синдром оцінювали за візуальною аналоговою шкалою (ВАШ), причому окремо оцінювали біль в поперековому відділі хребта та в нижніх кінцівках. Біль у спині у хворих II групи (оперативне лікування) не оцінювали до 1 місяця, оскільки хворі не могли адекватно оцінити біль через наявність післяопераційної рани. Для оцінки результатів лікування використовували модифікований критерій Macnab, де: відмінно - повна відсутність болю та симптомів, рухи без обмежень, повернення до роботи і активності; добре - загалом хворий задоволений, зменшення болю, повернення до роботи та звичайної щоденної активності, інколи прийом анальгетиків (парацетамол, моваліс); задовільно - функціональна активність незначно покращена, працездатність не відновлена; погано - без покращення, наявні корінцеві симптоми, необхідне повторне оперативне втручання; найгірше - клінічні симптоми стали гіршими ніж до лікування. Для оцінки регресу неврологічної симптоматики використовували модифіковану шкалу Nurick, де: I - неврологічні симптоми зникли; II - покращення стану; III - без змін; IV - погіршення неврологічного статусу, V - повне порушення неврологічних функцій нижче оперованого рівня. Також проводили опитування хворих згідно з Oswestry low back pain questionnaire та Japanese Orthopedic Association.

Результати досліджень та їх обговорення. Максимальний термін спостереження за хворими склав 10 років - 19 хворих ( 9 з I групи та 10 3 II групи); 6-10 років - 91 хворий (43 з I групи та 48 з II групи); 3-6 років - 158 хворих (68 3 
I групи та 90 з II групи); до 1-3 роки - 365 хворих (I група - 173 хворих, II група -145 хворих, III група - 47 хворих); до 1-го року - 486 хворих (I група - 284 хворих, II група - 11 хворих, III група - 191 хворий).

Відмінний та добрий результат серед усіх хворих першої групи, що спостерігались нами протягом першого року склав 68\%. Хворі регулярно проходили повторні курси лікування і серед тих хворих першої групи, яких ми мали змогу спостерігати протягом 6 років, відсоток відмінних та добрих результатів склав $63 \% .42$ хворих $з$ цієї групи були прооперовані через відсутність ефекту від консервативного лікування в різні терміни від початку терапії.

Серед хворих другої групи кількість відмінних та добрих результатів склала протягом першого року 74\%. Більшість хворих повернулись на свою попередню роботу. 37 хворих були вимушені змінити роботу. Повторно прооперовано 21 хворого: 18 хворих на інших рівнях та 3 хворих на рівні попереднього оперативного втручання. Серед хворих, яких ми спостерігали через 6 років, кількість відмінних та добрих результатів складала 70,5\%.

Середній рівень болю за ВАШ

\begin{tabular}{|c|c|c|c|c|c|c|}
\hline & & $\begin{array}{l}\text { До початку } \\
\text { лікування }\end{array}$ & $\begin{array}{c}\text { Через } 1 \\
\text { день }\end{array}$ & Через 1 рік & $\begin{array}{c}\text { Через } 3 \\
\text { роки }\end{array}$ & $\begin{array}{c}\text { Через } 6 \\
\text { років }\end{array}$ \\
\hline \multirow{2}{*}{$\begin{array}{l}\text { Консервативне лікування } \\
\text { (I група) }\end{array}$} & Спина & 7,5 & 5,7 & 3,9 & 4,6 & 5,3 \\
\hline & Нога & 7,2 & 4,9 & 2,1 & 2,8 & 2,9 \\
\hline \multirow{2}{*}{$\begin{array}{l}\text { Оперативне лікування } \\
\text { (II група) }\end{array}$} & Спина & 8,2 & & 2,8 & 3,9 & 4,5 \\
\hline & Нога & 7,5 & 0,8 & 0,8 & 2,2 & 2,8 \\
\hline \multirow{2}{*}{$\begin{array}{l}\text { Черезшкірна лазерна } \\
\text { вапоризація міжхребце- } \\
\text { вого диску } \\
\text { (III група) }\end{array}$} & Спина & 7,2 & 3,5 & 1,1 & 1,0 & 0,9 \\
\hline & Нога & 7,4 & 0,6 & 0,4 & 0,4 & 0,4 \\
\hline
\end{tabular}

Серед хворих III групи протягом 1 року успішні результати простежувалися в 77,1\%. У 15 хворих покращення не відмічалось. Один був прооперований відкритим методом. На операції було виявлено не діагностовану під час МРТ секвестровану килу диску. За багатьма хворими ми не змогли простежити 3 різних причин: дехто змінював адресу, деякі хворі продовжували лікування за місцем проживання, велика частка хворих була заробітчанами і виїхали за кордон, а дехто просто не приходив на контрольні огляди.

Згідно 3 опитувачем Oswestry low back pain questionnaire, середній відсоток серед хворих був
44,4\%. На контрольних оглядах цей показник склав $6,8 \%, 4,6 \%, 3,8 \%$ та $3,4 \%$ через $1,3,6$ та 12 місяців відповідно.

\section{Висновки.}

1. Черезшкірна лазерна вапоризація міжхребцевих дисків $є$ альтернативою відкритому хірургічному втручанню.

2. Необхідно дотримуватись чітких показів та протипоказів до виконання даного втручання.

3. Актуальним $\epsilon$ вивчення віддалених результатів (більше 6 років) після проведення черезшкірної лазерної вапоризації міжхребцевих дисків.

Інформація про конфлікт інтересів. Автори заявляють про відсутність конфлікту інтересів при виконанні наукового дослідження та підготовці цієї статті.

Інформація про фінансування. Автори гарантують, що вони не отримували жодних винагород у будь-якій формі, здатних вплинути на результати роботи.

Особистий внесок кожного автора у виконання роботи:

Шимон В.М. - розробив концепцію та дизайн дослідження, проводив консервативне та оперативне лікування хворих з остеохондрозом поперекового відділу хребта.

Стойка В.В. - збір та аналіз результатів дослідження, проводив лікування хворих і статистичну обробку одержаних результатів, підготовка та написання частини тексту.

Філіп С.С. - аналіз отриманих даних, підготовка та написання частини тексту, редагування.

Шерегій А.А., Пушкаш I.I. - брали участь у вибірці матеріалів, проводили лікування хворих, пошук літератури в інтернеті.

\section{Список використаної літератури}

1. Piontkovskyi V.K., Ashukina N.O., Maltseva V.Ye., \& Ivanov H.V. Vplyv radiochastotnoi abliatsii na mizhkhrebtsevyi dysk shchuriv pislia nukleotomii. Visnyk problem biolohii i medytsyny. 2018; 2(4 (147)). [In Ukrainian] 
2. Horbunov A.V., Potapov V.E., Sorokovikov V.A., Larionov S. N., \& Koshkareva Z. V. Opyt prymeneniia lazernoi vaporizatsii $\mathrm{v}$ lechenii hryzh mezhpozvonkovykh diskov v poiasnichnom otdele pozvonochnika. Acta Biomedica Scientifica. 2016; 1(4 (110)). [In Russian]

3. Zhang Y., You D., Gao X., Zhang N., \& Gao P.P. Welding defects detection based on deep learning with multiple optical sensors during disk laser welding of thick plates. Journal of Manufacturing Systems. 2019; 51: 87-94.

4. Choy DS. Percutaneous laser disc decompression (PLDD): twelve years' experience with 752 procedures in 518 patients. Journal of Clinical Laser Medicine \& Surgery. 1998; 16, (6): 325-331.

5. Belykh E., Yagmurlu K., Martirosyan N. L., Lei T., Izadyyazdanabadi M., Malik K. M.,... \& Preul M.C. Laser application in neurosurgery. Surgical neurology international. 2017; 8.

\section{Стаття надійшла до редакції: 15.10 .2020 р.}

